\title{
Recombinant production of Streptococcus equisimilis streptokinase by Streptomyces lividans
}

\author{
Elsa Pimienta ${ }^{1}$, Julio C Ayala ${ }^{1}$, Caridad Rodríguez ${ }^{1}$, Astrid Ramos ${ }^{1}$, Lieve Van \\ Mellaert ${ }^{2}$, Carlos Vallín*1 and Jozef Anné2
}

Address: ${ }^{1}$ Laboratorio de Genética, Departamento de Investigaciones Biomédicas, Centro de Química Farmacéutica. Ciudad de la Habana, Cuba and ${ }^{2}$ Laboratory of Bacteriology, Rega Institute, Katholieke Universiteit Leuven, B-3000 Leuven, Belgium

Email: Elsa Pimienta - epimienta@infomed.sld.cu; Julio C Ayala - julio.ayala@cnic.edu.cu; Caridad Rodríguez - caridad.rodriguez@cnic.edu.cu; Astrid Ramos - astridrm@yahoo.com; Lieve Van Mellaert - lieve.vanmellaert@rega.kuleuven.be; Carlos Vallín* - val@infomed.sld.cu; Jozef Anné - jozef.anne@rega.kuleuven.be

* Corresponding author

Published: 5 July 2007

Microbial Cell Factories 2007, 6:20 doi:10.1 I86/1475-2859-6-20
Received: 12 April 2007

Accepted: 5 July 2007

This article is available from: http://www.microbialcellfactories.com/content/6/1/20

(C) 2007 Pimienta et al; licensee BioMed Central Ltd.

This is an Open Access article distributed under the terms of the Creative Commons Attribution License (http://creativecommons.org/licenses/by/2.0), which permits unrestricted use, distribution, and reproduction in any medium, provided the original work is properly cited.

\begin{abstract}
Background: Streptokinase (SK) is a potent plasminogen activator with widespread clinical use as a thrombolytic agent. It is naturally secreted by several strains of beta-haemolytic streptococci. The low yields obtained in SK production, lack of developed gene transfer methodology and the pathogenesis of its natural host have been the principal reasons to search for a recombinant source for this important therapeutic protein. We report here the expression and secretion of SK by the Gram-positive bacterium Streptomyces lividans. The structural gene encoding SK was fused to the Streptomyces venezuelae CBS762.70 subtilisin inhibitor (vsi) signal sequence or to the Streptomyces lividans xylanase $C(x \ln C)$ signal sequence. The native Vsi protein is translocated via the Sec pathway while the native $\mathrm{X} \ln C$ protein uses the twinarginine translocation (Tat) pathway.

Results: SK yield in the spent culture medium of S. lividans was higher when the Sec-dependent signal peptide mediates the SK translocation. Using a $1.5 \mathrm{~L}$ fermentor, the secretory production of the Vsi-SK fusion protein reached up to $15 \mathrm{mg}$ SK/I. SK was partially purified from the culture supernatant by DEAESephacel chromatography. A 44-kDa degradation product co-eluted with the 47-kDa mature SK. The first amino acid residues of the $S$. lividans-produced SK were identical with those of the expected $\mathrm{N}$-terminal sequence. The Vsi signal peptide was thus correctly cleaved off and the $\mathrm{N}$-terminus of mature Vsi-SK fusion protein released by $S$. lividans remained intact. This result also implicates that the processing of the recombinant SK secreted by Streptomyces probably occurred at its C-terminal end, as in its native host Streptococcus equisimilis. The specific activity of the partially purified Streptomyces-derived SK was determined at $266 \mathrm{I} \mathrm{IU} / \mathrm{mg}$ protein.

Conclusion: Heterologous expression of Streptococcus equisimilis ATCC9542 skc-2 in Streptomyces lividans was successfully achieved. SK can be translocated via both the Sec and the Tat pathway in S. lividans, but yield was about 30 times higher when the SK was fused to the Sec-dependent Vsi signal peptide compared to the fusion with the Tat-dependent signal peptide of S. lividans xylanase C. Small-scale fermentation led to a fourfold improvement of secretory SK yield in S. lividans compared to lab-scale conditions. The partially purified SK showed biological activity. Streptomyces lividans was shown to be a valuable host for the production of a world-wide important, biopharmaceutical product in a bio-active form.
\end{abstract}




\section{Background}

Streptokinases are proteins translocated to the growth medium by many strains of beta-haemolytic streptococci. Streptokinase is not an enzyme per se but rather a potent activator that interacts with plasminogen to form a stoichiometric 1:1 complex. This interaction results in the activation of plasminogen to plasmin, which is the active fibrinolytic component of the circulatory system [1]. SK was the first drug introduced as a therapy for acute myocardial infarction more than 40 years ago [2]. It is now the leading fibrinolytic agent in the treatment of thromboembolic conditions [3] and is included in the World Health Organization Model List of Essential Medicines.

The Streptococcus equisimilis H46A skc gene encoding streptokinase has been cloned and expressed in several heterologous hosts due to the pathogenicity of its natural host. Haemolytic streptococci secrete several toxins that complicate the downstream purification. Besides, genetic modification of the natural host is restricted as rather few genetic tools are available. As a result, the recombinant production of this protein in $E$. coli has been widely used, including the use of the protein SKC-2 naturally secreted by Streptococcus equisimilis ATCC 9542 [4,5]. High-level expression of $s k c$ in $E$. coli has been reported, but the formation of inclusion bodies consisting of highly aggregated SK molecules makes its recovery in an active form difficult $[4,5]$. High level of intracellular SK has also been obtained during continuous fermentation of recombinant Pichia pastoris but protein recovery requires cell lysis [6].

Since the recovery of extracellular proteins is generally easier than that of cytoplasmic proteins, the expression and subsequent secretion of SK have been studied in several heterologous hosts like Escherichia coli, Bacillus subtilis and Pichia pastoris [7-9]. In case of B. subtilis, the use of the sixextracellular-protease-deficient strain, WB600, greatly improved the yield of recombinant SK. The protein was also secreted into the culture medium by $P$. pastoris, but it was found to be heavily glycosylated. The biological activity of both secreted streptokinases was proved. A recent study using Schizosaccharomyces pombe as host, reported the expression of SK and its secretion into the periplasmic fraction without glycosylation and significant degradation or modification. However, conventional chromatographic approaches used before to purify SK from other hosts were inadequate because of cofractionation of a few proteins of similar size with SK through all the chromatographic steps [10].

As it is not possible to predict which host will be the best for the production of a protein, the aim of this work was to evaluate Streptomyces lividans as host for recombinant production of SK. S. lividans has been successfully used for the production of several proteins of bacterial and eukary- otic origin [11-13]. The advantages of the S. lividans host include its natural ability to secrete high levels of bioactive molecules into the extracellular medium, limited protease activity, its biological safety and well-established fermentation technology [14]. In the present study, the S. lividans system has been tested for the secretory production of the streptokinase from Streptococcus equisimilis group C by using the Sec and the recently described twin-arginine translocation (Tat) pathway in S. lividans [15]. The sequence encoding mature SK was fused to the Secdependent signal sequence of Streptomyces venezuelae CBS762.70 subtilisin inhibitor [16] and the twin-arginine signal sequence of $S$. lividans xylanase C [17], respectively. SK production in S. lividans was evaluated and purification of the secreted SK protein was carried out.

\section{Results \\ Construction of SK expression/secretion vectors}

In order to establish the expression and secretion of SK from Streptococcus equisimilis ATCC9542 in S. lividans, the $s k c-2$ gene was amplified by PCR using chromosomal DNA as template and finally cloned in appropriate vectors in Streptomyces. The constructed expression/secretion vectors pOVsiSK and pOXInCSK encode the fusion proteins Vsi-SK and XlnC-SK, respectively (Table 1). Vsi-SK consists of the Sec-dependent Vsi signal peptide, the first two amino acid residues of mature Vsi followed by the mature SK, while XlnC-SK is composed of the Tat-dependent $\mathrm{X} \ln C$ signal peptide, the first three amino acids of mature $\mathrm{X} \operatorname{lnC}$ and mature SK. In this way, the signal peptidase cleavage sites of Vsi and $\mathrm{XInC}$ are remained and a proper processing of the precursor proteins is achieved. Both fusion genes were placed under control of the vsi promoter, of which has been proved that it efficiently promotes heterologous gene expression $[13,16]$.

\section{Secretion of SK by S. lividans}

S. lividans transformants carrying pOVsiSK and pOXl$\mathrm{nCSK}$, respectively, were grown at lab scale in rich BTSB medium and at several time intervals the presence of SK in the culture filtrate was assessed by Western blot analysis. A clear SK-specific band of about $47 \mathrm{kDa}$ and smaller immunoreactive bands of approximately $44 \mathrm{kDa}$ and 32 $\mathrm{kDa}$ could be observed in culture supernatant of $S$. lividans [pOVsiSK] at 30 and $40 \mathrm{~h}$ of growth (Fig. 1, lanes 3 and 4). SK was faintly detectable in culture filtrate of $S$. lividans [pOXInCSK] upon 30 and $40 \mathrm{~h}$ growth (Fig. 1, lanes 5 and 6 ). No SK-specific immunoreactive proteins could be detected in cell lysates of $S$. lividans carrying pOVsiSK or pOXInCSK (data not shown), which indicated that the produced preproteins did not accumulate inside the cell and were efficiently translocated through the cell membrane. 
Table I: Plasmids used in this study.

\begin{tabular}{|c|c|c|}
\hline Name & Relevant properties & Source or reference \\
\hline PGEM-SK & pGEM $^{\circledR}$-T Easy derivative containing the Streptococcus equisimilis skc-2 gene & This work \\
\hline PBS-CBSS & $\begin{array}{l}\text { pBluescript } \mathrm{KS}(+) \text { derivative containing the Streptomyces venezuelae vsi promoter and part of the mature } \\
\text { vsi gene }\end{array}$ & [16] \\
\hline pBSVX & $\begin{array}{l}\text { pBluescript KS(+) derivative containing the Streptomcyes venezuelae vsi promoter and the signal } \\
\text { sequence of Streptomyces lividans } x \ln C\end{array}$ & {$[17]$} \\
\hline pBSVXM & $\begin{array}{l}\text { pBSVX derivative containing a unique EcoRI site downstream of the signal sequence of Streptomyces } \\
\text { lividans } x \ln C\end{array}$ & This work \\
\hline pUWL-218 & Escherichia coli-Streptomyces shuttle vector, multiple cloning site, $A p^{R}, T s r^{R}$ & {$[40]$} \\
\hline pOWI5 & $\begin{array}{l}\text { PUWL- } 2 \text { I } 8 \text { derivative } E \text {. coli-Streptomyces shuttle vector containing the oriT fragment for interspecies } \\
\text { DNA conjugation. }\end{array}$ & Rosabal et al., unpublished. \\
\hline pOVsiSK & $\begin{array}{l}\text { pOWI5 derivative containing the Streptomyces venezuelae vsi promoter, and signal sequence, and the } \\
\text { Streptococcus equisimilis skc- } 2 \text { gene }\end{array}$ & This work \\
\hline pOXInCSK & $\begin{array}{l}\text { pOWI5 derivative containing the Streptomyces venezuelae vsi promoter, the Streptomyces lividans } x \ln C \\
\text { signal sequence and the Streptococcus equisimilis skc-2 gene }\end{array}$ & This work \\
\hline
\end{tabular}

The amount of SK secreted by the S. lividans transformants, measured by means of ELISA, reached a maximum around $40 \mathrm{~h}$ and then decreased. Upon $40 \mathrm{~h}$ growth, up to $4 \mathrm{mg} \mathrm{SK} / \mathrm{l}$ medium was measured in culture supernatant of S. lividans [pOVsiSK] (Fig. 2), while 100-150 $\mu \mathrm{g} \mathrm{SK/l}$ was detected in the extracellular fraction of 40-h S. lividans [pOXInCSK] cultures. These results indicate that SK can be translocated via both the Sec and the Tat pathway in S. lividans, but the Sec-routed secretion leads to higher levels of the recombinant protein.

In consequence of the poor SK yield using the XlnC signal peptide as mediator for translocation, only $S$. lividans [pOVsiSK] was tested under fermentation conditions.

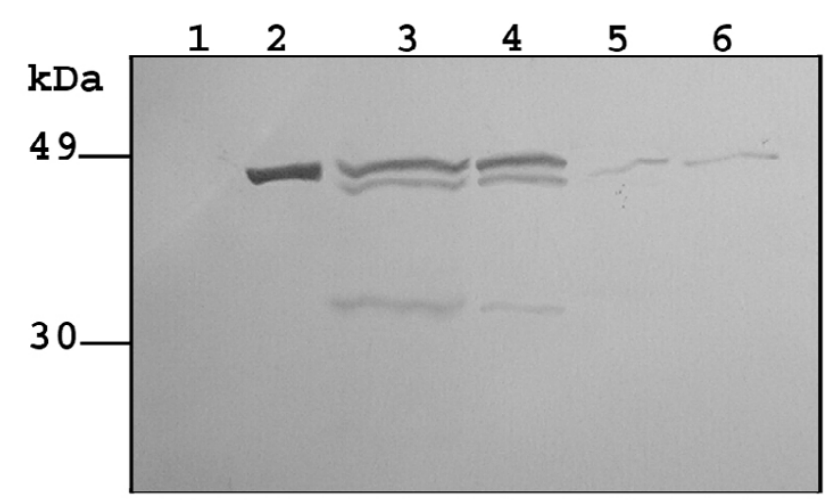

Figure I

Immunodetection of SK in extracellular fractions.

Proteins from culture supernatants were precipitation with a mixture of chloroform and methanol $(1: 3, \mathrm{v} / \mathrm{v})$. In each lane, proteins according to $100 \mu \mathrm{l}$ spent culture medium were loaded. Lane I, S. lividans [pOWI5] 40 h; lane 2, 60 ng SK standard; lane 3, S. lividans [pOVsiSK] $30 \mathrm{~h}$; lane 4, S. lividans [pOVsiSK] 40 h; lane 5, S. lividans [POXInCSK] 30 h; lane 6, S. lividans [POXInCSK] $40 \mathrm{~h}$.
Using small-scale fermentation conditions, the secretory SK production reached up to $15 \mathrm{mg} \mathrm{SK} / \mathrm{l}$, which corresponds to a fourfold improvement of secretory SK yield in S. lividans compared to lab-scale conditions.

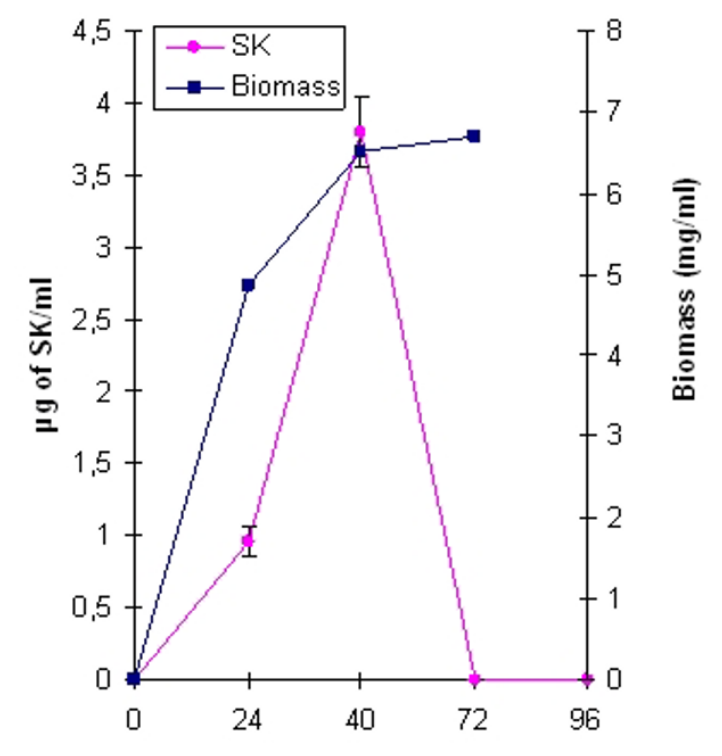

Time (h)

Figure 2

Secretory yield of recombinant SK correlated with biomass of Streptomyces lividans [pOVsiSK] grown in lab-scale conditions. SK concentration was determined by means of ELISA. Growth was estimated by measuring biomass dry weight $(\mathrm{mg} / \mathrm{ml})$, standard errors were between 0.1 and 0.2 . 


\section{Purification of recombinant SK secreted by S. lividans}

Having defined the fermentation conditions for the secretory production of recombinant $\mathrm{SK}$, the protein was purified from the extracellular culture fraction. The protein fraction obtained through ammonium sulfate precipitation (45\% saturation) was dissolved in $20 \mathrm{mM}$ Tris-HCl ( $\mathrm{pH}$ 6.0), dialyzed against the same buffer and then applied on a DEAE-Sephacel column. The proteins were eluted in $20 \mathrm{mM}$ Tris-HCl, $150 \mathrm{mM} \mathrm{NaCl}, \mathrm{pH}$ 6.0. Samples from the various purification steps were analysed by SDS-PAGE followed by Coomassie staining (Fig. 3A) and immunodetection of the recombinant SK using a monoclonal anti-SK antibody (Fig. 3B). Samples from culture supernatant and $45 \%$ ammonium sulphate saturation fraction of S. lividans TK 24 [pOW15] were included as negative controls (Fig. 3, lanes 1 and 2). This experiment revealed that the purified proteins correspond to SK. Pooled elution fractions with a purity grade of 58\% contained the $44-\mathrm{kDa}$ degradation product which co-eluted with the 47-kDa mature SK.

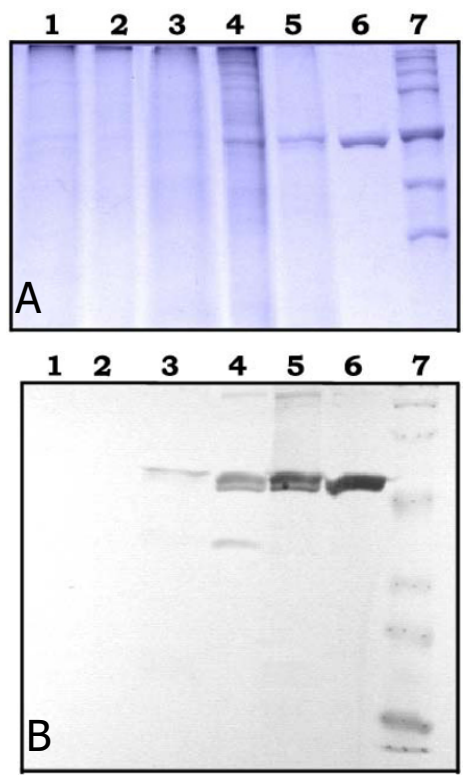

\section{Figure 3}

Purification of extracellular SK from S. lividans culture supernatants upon small-scale fermentation. (A) I0\% SDS-PAGE stained with Coomassie blue R-250, and (B) Immunoblotting analysis using a monoclonal anti-SK antibody. Lane I, $25 \mu \mathrm{g}$ of crude extract of S. lividans TK24 [pOWI5]; lane 2, $25 \mu \mathrm{g}$ of material precipitated with $\left(\mathrm{NH}_{4}\right)_{2} \mathrm{SO}_{4}$ of $\mathrm{S}$. lividans TK24 [pOWI5]; lane 3, $25 \mu \mathrm{g}$ of crude extract of $S$. lividans TK24 [pOVsiSK]; lane 4, $25 \mu \mathrm{g}$ of proteins precipitated with $\left(\mathrm{NH}_{4}\right)_{2} \mathrm{SO}_{4}$ of $\mathrm{S}$. lividans TK24 [pOVsiSK]; lane 5, $25 \mu \mathrm{g}$ of pooled anion exchange chromatography protein fractions with $58 \%$ purity; lane 6 , I $\mu$ g of SK standard; lane 7, Broad-range protein molecular weight markers.
In order to determine the specificity of signal peptidase processing and the nature of the approximately $44-\mathrm{kDa}$ protein, an N-terminal sequence was carried out on both the 47- and 44-kDa proteins obtained from S. lividans TK 24 [pOVsiSK] culture supernatant. N-terminal residues of both purified proteins were those predicted from the sequence (Table 2). The Vsi signal peptide was thus correctly cleaved off and the N-terminus of mature Vsi-SK released by $S$. lividans remained intact. This result also implicates that the processing of mature Vsi-SK secreted by Streptomyces occurred at its C-terminal end.

The specific activity of the partially purified proteins secreted by $S$. lividans [pOVsiSK] was amounted to 2661 $\mathrm{IU} / \mathrm{mg}$ protein (Table 3 ). In consequence of incompatibility between the crude culture medium and the chromogenic substrate assay, we were not able to determine the initial specific activity of SK.

\section{Discussion}

In the present study, it was shown that SK from Streptococcus equisimilis ATCC 9542 could be efficiently secreted in a bio-active form via the Sec pathway in Streptomyces lividans. Sec-routed secretion was obtained by using the regulatory signal sequences of $S$. venezuelae CBS762.70 subtilisin inhibitor gene. The Tat translocation route was also tested for the secretion of SK in S. lividans by means of a fusion of SK to the Tat-dependent signal peptide of $S$. lividans xylanase C. Yield was about 30 times higher when the SK was fused to the Sec-dependent Vsi signal peptide compared to the fusion with the Tat-dependent XlnC signal peptide. Although the use of the Tat pathway in most cases does not result in higher production yield compared to Sec-mediated secretion (e.g. Schaerlaekens et al. 2004), some proteins need to be secreted via the Tat pathway to obtain their bio-active conformation. This is the case for the homologous protein xylanase C [18], but also for the heterologous enhanced green fluorescent protein (EGFP) [19].

The maximum level of SK secreted by S. lividans was 15 $\mathrm{mg} / \mathrm{l}$ of culture, but as a result of incompatibility between the crude culture medium and the chromogenic substrate assay, we were not able to determine the initial activity of

Table 2: Amino acid sequence of the fusion region of preVsi-SK and the $\mathrm{N}$-terminal amino acid sequence of the 47- and 44-kDa proteins obtained from S. lividans TK 24 [pOVsiSK] culture supernatant.

\begin{tabular}{cc}
\hline Protein & Amino acid sequence \\
\hline PreVsi-SK (fusion region) & ...A Q A $\downarrow$ E A I A G P E W L L... \\
N-terminus 47-kDa rSK & E A I A G P E W L L... \\
N-terminus 44-kDa rSK & E A I A G P E W L L...
\end{tabular}

$\downarrow$ : Signal peptidase cleavage site, SK sequence in italics 
Table 3: Secretory production of recombinant SK by S. lividans TK 24 [pOVsiSK].

\begin{tabular}{|c|c|c|c|c|c|}
\hline Sample & Volume $(\mathrm{ml})$ & SK activity $(\mathrm{IU} / \mathrm{ml})$ & $\begin{array}{c}\text { Protein concentration } \\
(\mathrm{mg} / \mathrm{ml})\end{array}$ & ELISA SK (mg/ml) & $\begin{array}{c}\text { Specific activity } \\
\text { (IU/mg) }\end{array}$ \\
\hline Culture supernatant & 1000 & ND & 1.04 & 0.015 & ND \\
\hline DEAE eluates with $58 \%$ purity & 16 & $444 \pm 24$ & 0.17 & 0.021 & $2661 \pm 29$ \\
\hline
\end{tabular}

ND: No determined.

Streptomyces-derived SK. SK secreted by recombinant $S$. lividans was partially purified (58\% purity) and was found biologically active with an specific activity of $2661 \mathrm{IU} / \mathrm{mg}$ protein. In addition, it is not possible to compare reliably the plasminogen activity of the partially purified SK secreted by Streptomyces with the initial SK activity secreted by other hosts like: Streptococcus equisimilis (100-150 IU/ $\mathrm{ml})$, E. coli (1000-1500 IU/ml), P. pastoris (3200 IU/m1) or $S$. pombe (2450 IU/m1) [9,10]. However, it is possible to establish a relative comparison with the total yield $(24.5 \mathrm{mg} / \mathrm{l})$ and the initial specific activity of SK secreted by $S$. pombe (1581 IU/mg protein) [10].

SK has a tendency to degrade very easily [20,21]. Several hosts, including the native host Streptococcus equisimilis, produce at least two major forms of SK $[7,8,22]$ : the intact mature SK with a molecular mass of $47 \mathrm{kDa}$ and a $44-\mathrm{kDa}$ degradation product. This degradation product lacks 31 or 32 C-terminal residues whereas it retains the plasminogen activation capability [23]. Furthermore, C-terminal deletion mutants of SK lacking 40 [24] or 41 amino acids [25] exhibited normal plasminogen activator function. In addition to the 47- and 44-kDa bands, a 32-kDa degradation product was detected by Western blot. Since SK proteins which lack 18 or more N-terminal or 51 or more Cterminal amino acid residues are unlikely to be effective thrombolytic agents [24], the 32-kDa SK-related protein missing about 135 aa residues was not further investigated.

It was demonstrated that the post-translational modification at the C-terminus of native SK was caused by chymotrypsin-like activity [23]. Similar degradation of recombinant SK has been also reported to occur in heterologous hosts such as Streptococcus sanguis [23] and E. coli [26]. Chymotrypsin-like activity and several genes encoding chymotrypsin-like serine proteases have been reported in $S$. lividans $66[27,28]$. Since the first amino acid residues of the S. lividans-produced Vsi-SK were identical to those of the expected $\mathrm{N}$-terminal sequence, the recombinant protein was proteolytically degraded at its C-terminal end.

In case of recombinant SK production in Lactococcus lactis, the protease susceptibility and hence the productivity of SK was dependent on the $\mathrm{pH}$ of the culture and the initial phosphate concentration of the medium. Suppression of the acid tolerance response, by which protease expression is induced, enhanced the SK yield 2.5 fold [29]. Results of a differential scanning calorimetry study on $E$. coli-derived recombinant $S$. equisimilis SK firmly indicated that at neutral and basic $\mathrm{pH}$, the recombinant SK from Streptococcus equisimilis group C (ATCC 9542) has four domains, whereas gentle changes in the experimental conditions, such as mild acidification or increase in the $\mathrm{NaCl}$ concentration, decreased this number [30]. Consequently, $\mathrm{pH}$ and ionic strength of the production medium define the conformational status of SK and are thus important factors determining the protease susceptibility of the recombinant protein.

The specific activity of the partially purified SK (58\% purity) secreted by $S$. lividans [pOVsiSK] was determined at $2661 \mathrm{IU} / \mathrm{mg}$ protein. We believe that further up-scaling of the fermentation process and optimisation of production medium and purification protocol, will surely improve yield of recombinant bio-active SK in S. lividans.

\section{Conclusion}

Heterologous expression of Streptococcus equisimilis ATCC9542 skc-2 in Streptomyces lividans was successfully achieved. SK can be translocated via both the Sec and the Tat pathway in S. lividans, but yield was about 30 times higher when the SK was fused to the Sec-dependent Vsi signal peptide compared to the fusion with the Tatdependent signal peptide of S. lividans xylanase C. Smallscale fermentation led to a fourfold improvement of secretory SK yield in S. lividans compared to lab-scale conditions. The plasminogen activity of the partially purified SK (58\% purity) secreted by S. lividans [pOVsiSK] was determined at $2661 \mathrm{IU} / \mathrm{mg}$ protein. Once more, Streptomyces lividans was shown to be a valuable host for the production of a world-wide important, biopharmaceutical product in a bio-active form.

\section{Methods}

\section{Bacterial strains and growth conditions}

E. coli TG1 was used as host for cloning purposes. Culture conditions for E. coli were as described by Sambrook et al. [31]. Streptococcus equisimilis ATCC9542 cells were grown as described by Estrada et al. [4]. Streptomyces lividans TK24 was selected as host for heterologous protein production. Protoplast formation and subsequent transfor- 
mation of S. lividans were carried out as described by Kieser et al. [32]. Regeneration of S. lividans protoplasts and selection of transformants was carried out on MRYE medium [33]. When appropriate, thiostrepton $(50 \mu \mathrm{g} / \mathrm{ml}$ in solid medium or $10 \mu \mathrm{g} / \mathrm{ml}$ in liquid medium) was added. Spore suspensions of S. lividans TK24 and derivatives were stored at $-70^{\circ} \mathrm{C}$ in $20 \%(\mathrm{v} / \mathrm{v})$ glycerol. Primary cultures of $S$. lividans strains were routinely cultured for 72 $\mathrm{h}\left(28^{\circ} \mathrm{C}, 240 \mathrm{rpm}\right)$ in BTSB, which is a modified version of the medium described by Dyson and Schrempf [34]: $10 \%$ sucrose, $1 \%$ yeast extract, $1 \%$ glucose, $0.5 \% \mathrm{NaCl}$, $0.5 \%$ soya flour, $1.7 \%$ tryptone, $0.25 \% \mathrm{~K}_{2} \mathrm{HPO}_{4}$, $\mathrm{pH} 7.2$. For monitoring recombinant protein expression and secretion, 1-ml primary cultures were inoculated to $0.5-\mathrm{L}$ shake flask containing $0.1 \mathrm{~L}$ of BTSB medium and grown for $40 \mathrm{~h}$ at $28^{\circ} \mathrm{C}$ and $300 \mathrm{rpm}$. For production of SK, the recombinant strain was cultured for $48 \mathrm{~h}\left(28^{\circ} \mathrm{C}, 350\right.$ $\mathrm{rpm}$ ) in a 2.5-L MBR reactor containing $1.5 \mathrm{~L}$ BTSB medium. The $\mathrm{pH}$ was controlled at 7.0 by the addition of $5 \mathrm{~N} \mathrm{NaOH}$.

\section{Plasmid construction and recombinant DNA technology}

DNA manipulations were carried out following standard procedures [31,32]. Restriction endonucleases and DNAmodifying enzymes were from Invitrogen and Roche Diagnostics. Upon isolation of S. equisimilis ATCC9542 chromosomal DNA as described by Estrada et al. [4], the $s k c-2$ gene was PCR-amplified from the chromosome under standard conditions using the oligonucleotides SKF1 and SK-R1 (see Table 4) and Taq polymerase. To allow in-frame fusion of the $s k c-2$ gene downstream the signal sequences, the oligonucleotide SK-F1 was designed with an EcoRV site (GATATC) in its 5'end. Consequently, a silent mutation was introduced in the first codon of the mature part of the $s k c-2$ gene: ATT was replaced by ATC, both encoding isoleucine.

The 1245-bp PCR fragment was ligated into pGEM $^{\circledR}$-T Easy (Promega) and the resulting plasmid was denominated PGEM-SK. The DNA sequence was verified using the Thermo Sequenase Primer Cycle Sequencing Kit with 7 deaza-dGTP on an ALFexpress apparatus (Amersham Biosciences, Rainham, UK). Subsequently, the 1.3-kb EcoRV/ EcoRI fragment of pGEM-SK was cloned into pBS-CBSS [16] successively treated with DraII, Klenow polymerase and EcoRI. The unique DraII site in pBS-CBSS is located two codons downstream the signal peptidase recognition site. $s k c-2$ was also cloned into PBSVXM, a derivative of plasmid pBSVX [17] missing an EcoRI site. To remove the EcoRI site located upstream the vsi promoter in pBSVX, a site-directed mutagenesis was carried out by means of PCR using $P f u$ polymerase and the mutagenic oligonucleotides PBSXylE-F and -R (Table 4), which contain the desired mutation. As such, a unique EcoRI site located downstream the $S$. lividans $x \ln C$ signal sequence was available. In order to insert the $s k c-2$ gene fused to the third codon of mature $x \ln C$, the vector PBSVXM was digested with NsiI, treated with T4 DNA polymerase removing the 3 '-protruding ends and finally treated with EcoRI. DNA sequence analyses of the newly constructed fusion genes confirmed their correctness.

Finally, both expression/secretion cassettes were isolated as Bam HI/EcoRI-fragments and ligated in BamHI/EcoRIdigested pOW15. The vector with the vsi signal sequence was designated pOVsiSK and the vector with the $x \ln C$ signal sequence was denominated pOXInCSK. Plasmids used in this study are listed in Table 1.

\section{Detection of SK}

The detection of SK in culture supernatants and cell lysates of S. lividans transformed with pOVsiSK or pOXInCSK was performed using Western Blot and immunodetection. Gel electrophoresis of proteins was carried out on 10\% SDSpolyacrylamide gels [35]. Separated proteins were visualized by Coomassie brilliant blue staining or transferred to a Hybond ${ }^{\mathrm{TM}}$-C extra membrane (GE Healthcare) by using a semidry transfer cell (Biometra) according to the manufacturer's recommendations. SK was detected using a mouse anti-SK monoclonal antibody (produced by Center for Genetic Engineering and Biotechnology, Sancti Spiritus, Cuba). HRP-conjugated goat anti-mouse antibody (Promega) was used as secondary antibody. Immunoreactive bands were visualized by brief exposure to 3,3diaminobenzidine or 4-chloro naftol (Sigma). Cell lysates were obtained according to Pimienta et al. [36]. The protein content of culture supernatants, cell lysates and purified fractions was determined using the Bradford method [37].

Table 4: Oligonucleotides used in this study.

\begin{tabular}{clc}
\hline Name & Sequence (5'-3' direction) & Restriction sites (in italic) \\
\hline SK-FI & GATATCGCTGGACCTGAGTGGCTG & EcoRV \\
SK-RI & AGATCTTATTTGTCGTTAGGGTTATCAG & BgllI \\
PBSXyIE-F & CCGGGCTGCAGGAAGTCGATTCGGGAGCG & - \\
PBSXYIE-R & CGCTCCCGAATCGACTTCCTGCAGCCCGG & -
\end{tabular}

The mutagenic base is in bold face. 
The molecular size and the purification degree of recombinant SK protein were estimated from densitometric scanning of Coomassie brilliant blue-stained gels using a GENE GENIUS gel documentation system and GeneTools software (Syngene).

SK present in culture supernatants or anion exchange chromatography eluates was quantified by means of a general sandwich ELISA protocol (Abrahantes et al. unpublished results). The SK standard was kindly supplied by the Development Division, Center for Genetic Engineering and Biotechnology, Havana, Cuba. The coefficient of variation of the ELISA tests was less than $10 \%$.

SK activity was monitored spectrophotometrically at 405 $\mathrm{nm}$ in a coupled SK-plasminogen assay employing the chromogenic substrate S-2251 (Kabi, Sweden) according to Hernández et al. [38]. The specific activity $(\mathrm{IU} / \mathrm{mg})$ was calculated by dividing the SK activity (IU/ml) with protein concentration $(\mathrm{mg} / \mathrm{ml})$.

\section{Protein purification and chromatography}

For purification of SK from recombinant S. lividans cultures, strains were grown for 2 days in $200 \mathrm{ml}$ BTSB medium. Then, cultures were centrifuged and the mycelium was resuspended in $0.1 \mathrm{~L}$ of water. This suspension was transferred to $1.5 \mathrm{~L}$ BTSB in the MBR reactor and bacterial growth was continued for 2 days. Culture supernatant proteins were precipitated by addition of $\left(\mathrm{NH}_{4}\right)_{2} \mathrm{SO}_{4}$ $\left(45 \%\right.$ saturation, $\left.4^{\circ} \mathrm{C}\right)$ and collected by centrifugation (Hettich Universal 32R centrifuge, Sorvall, 1620A rotor, $4^{\circ} \mathrm{C}, 20 \mathrm{~min}, 8000 \times \mathrm{g}$ ). The protein pellets were left overnight at $4{ }^{\circ} \mathrm{C}$ in $0.1 \mathrm{~L}$ of $20 \mathrm{mM}$ Tris- $\mathrm{HCl}$ buffer, $\mathrm{pH}$ 6.0. Then, the protein solution was dialyzed against $20 \mathrm{mM}$ Tris-HCl buffer ( $\mathrm{pH} \mathrm{6.0)}$ at $4{ }^{\circ} \mathrm{C}$ for $20 \mathrm{~h}$ and was finally applied on a DEAE Sephacel column equilibrated with 20 mM Tris-HCl buffer, pH 6.0. The column was extensively washed with the mentioned buffer followed by 1 column volume of $20 \mathrm{mM}$ Tris-HCl, $20 \mathrm{mM} \mathrm{NaCl}$, pH 6.0. SK protein elution from the DEAE Sephacel column was carried out with 3 column volumes of $20 \mathrm{mM}$ Tris- $\mathrm{HCl}, 150 \mathrm{mM}$ $\mathrm{NaCl}, \mathrm{pH} 6.0$ at a flow rate of $0.5 \mathrm{ml} / \mathrm{min}$. One $\mathrm{ml}$ fractions were collected. Fractions containing SK with a similar degree of purity, determined by means of SDS-PAGE followed by Coomassie staining, were pooled.

\section{N-terminal amino acid sequence analysis}

The purified SK was subjected to SDS-PAGE and blotted on a Hybond-P membrane (GE healthcare) as described by Ausubel et al. [39]. After Coomassie staining, the relevant protein bands were excised and subjected to sequencing. The N-terminal amino acid sequence of recombinant SK was determined by Edman degradation using an automatic 477A-1201 protein sequencing system (Applied Biosystems).

\section{Competing interests}

The author(s) declare that they have no competing interests.

\section{Authors' contributions}

EP participated in the design of the study, performed clonings, strain constructions and fermentation, analyzed the data and wrote the manuscript. JCA participated in design and performance of protein purification. CR participated in design and performance of protein purification. AR participated in design and performance of growth conditions. LVM, CV and JA participated in design of the study and commented the manuscript. All authors have read and approved the manuscript.

\section{Acknowledgements}

Part of this work was supported by the Research Project ZEIN2002PR262 of the "Vlaams interuniversitaire raad"/University Development Cooperation in collaboration" with the Rega Institute, Katholieke Universiteit Leuven, Belgium. We thank Prof. Paul Proost (Rega Institute, K.U. Leuven) for $\mathrm{N}$-terminal amino acid determinations. The assistance provided by Ing. Lázara Muñoz, Bsc. Dinorah Torres, Ing. Jorge Valdés and Dr. Eduardo Martínez from the Development Division, Center for Genetic Engineering and Biotechnology, Cuba is thankfully acknowledged.

\section{References}

I. Malke H, Ferretti J): Streptokinase: cloning, expression, and excretion by Escherichia coli. Proc Natl Acad Sci USA 1984, 81:3557-356l.

2. Sherry S, Fletcher AP, Alkjaersig N: Fibrinolysis and fibrinolytic activity in man. Physiol Rev 1959, 39:343-382.

3. Boersma E, Mercado N, Poldermans D, Gardien M, Vos J, Simoons ML: Acute myocardial infarction. Lancet 2003, 361 :847-858.

4. Estrada MP, Hernandez L, Perez A, Rodriguez P, Serrano R, Rubiera $R$, et al: High level expression of streptokinase in Escherichia coli. Biotechnology (NY) 1992, I 0: I | 38- | | 42.

5. Zhang XW, Sun T, Huang XN, Liu X, Gu DX, Tang ZQ: Recombinant streptokinase production by fed-batch cultivation of Escherichia coli. Enzyme Microb Technol 1999, 24:647-650.

6. Hagenson MJ, Holden KA, Parker KA, Wood PJ, Cruze JA, Fuke M, et al.: Expression of streptokinase in Pichia pastoris yeast. Enzyme Microb Technol 1989, I I:650-656.

7. Ko JH, Park DK, Kim IIC, Lee SH, Byun SM: High level expression and secretion of streptokinase in Escherichia coli. Biotechnol Lett 1995, I7:I19-1024.

8. Wong SL, Ye R, Nathoo S: Engineering and production of streptokinase in a Bacillus subtilis expression-secretion system. Appl Environ Microbiol 1994, 60:517-523.

9. Pratap J, Rajamohan G, Dikshit KL: Characteristics of glycosylated streptokinase secreted from Pichia pastoris: enhanced resistance of SK to proteolysis by glycosylation. Appl Microbiol Biotechnol 2000, 53:469-475.

10. Kumar R, Singh J: Expression and secretion of a prokaryotic protein streptokinase without glycosylation and degradation in Schizosaccharomyces pombe. Yeast 2004, 2 I : I 343- I 358.

II. Hong B, Wu B, Li Y: Production of C-terminal amidated recombinant salmon calcitonin in Streptomyces lividans. Appl Biochem Biotechnol 2003, I I 0: I I3-I 23.

12. Lara M, Servin-Gonzalez L, Singh M, Moreno C, Cohen I, Nimtz M, et al.: Expression, secretion, and glycosylation of the 45- and 47kDa glycoprotein of Mycobacterium tuberculosis in Streptomyces lividans. Appl Environ Microbiol 2004, 70:679-685.

13. Sianidis G, Pozidis C, Becker F, Vrancken K, Sjoeholm C, Karamanou $\mathrm{S}$, et al.: Functional large-scale production of a novel Jonesia sp. xyloglucanase by heterologous secretion from Streptomyces lividans. J Biotechnol 2006, I 2 I:498-507. 
14. Van Mellaert L, Anné J: Protein secretion in Gram-positive bacteria with high GC-content. Recent Res Dev Microbiol 1999, 3:425-440.

15. Schaerlaekens K, Schierova M, Lammertyn E, Geukens N, Anné J, Van Mellaert L: Twin-arginine translocation pathway in Streptomyces lividans. J Bacteriol 200I, 183:6727-6732.

16. Lammertyn E, Van Mellaert L, Schacht S, Dillen C, Sablon E, Van Broekhoven A, et al.: Evaluation of a novel subtilisin inhibitor gene and mutant derivatives for the expression and secretion of mouse tumor necrosis factor alpha by Streptomyces lividans. Appl Environ Microbiol 1997, 63:1808-18I3.

17. Schaerlaekens K, Lammertyn E, Geukens N, De Keersmaeker S, Anné J, Van Mellaert L: Comparison of the Sec and Tat secretion pathways for heterologous protein production by Streptomyces lividans. I Biotechnol 2004, I I 2:279-288.

18. Faury D, Saidane S, Li H, Morosoli R: Secretion of active xylanase C from Streptomyces lividans is exclusively mediated by the Tat protein export system. Biochim Biophys Acta 2004, 1699:155-162.

19. Vrancken K, De Keersmaeker S, Geukens N, Lammertyn E, Anné J, Van Mellaert L: pspA overexpression in Streptomyces lividans improves both Sec- and Tat-dependent protein secretion. Appl Microbiol Biotechnol 2007, 73: I I50-I I 57.

20. Castellino FJ, Sodetz JM, Brockway WJ, Siefring GE Jr: Streptokinase. Methods Enzymol 1976, 45:244-257.

21. Shi GY, Chang BI, Chen SM, Wu DH, Wu HL: Function of streptokinase fragments in plasminogen activation. Biochem J 1994, 304(Pt I):235-24I.

22. Malke H, Gerlach D, Kohler W, Ferretti J]: Expression of a streptokinase gene from Streptococcus equisimilis in Streptococcus sanguis. Mol Gen Genet 1984, 196:360-363.

23. Jackson KW, Malke H, Gerlach D, Ferretti JJ, Tang J: Active streptokinase from the cloned gene in Streptococcus sanguis is without the carboxyl-terminal 32 residues. Biochemistry 1986, 25: I08-II4.

24. Fay WP, Bokka LV: Functional analysis of the amino- and carboxyl-termini of streptokinase. Thromb Haemost 1998, 79:985-991.

25. Kim IC, Kim JS, Lee SH, Byun SM: C-terminal peptide of streptokinase, Met369-Pro373, is important in plasminogen activation. Biochem Mol Biol Int 1996, 40:939-945.

26. Avilán L, Yarzábal A, Jürgensen C, Bastidas M, Cruz J, Puig J: Cloning, expression and purification of recombinant streptokinase: partial characterization of the protein expressed in Escherichia coli. Braz J Med Biol Res 1997, 30: |427-| 430

27. Aretz W, Koller KP, Riess G: Proteolytic enzymes from recombinant Streptomyces lividans TK24. FEMS Microbiol Lett 1989, 53:3I-35.

28. Binnie C, Liao L, Walczyk E, Malek LT: Isolation and characterization of a gene encoding a chymotrypsin-like serine protease from Streptomyces lividans 66. Can J Microbiol 1996, 42:284-288.

29. Sriraman K, Jayaraman G: Enhancement of recombinant streptokinase production in Lactococcus lactis by suppression of acid tolerance response. Appl Microbiol Biotechnol 2006, 72:1202-1209

30. Beldarrain A, Lopez-Lacomba JL, Kutyshenko VP, Serrano R, Cortijo M: Multidomain structure of a recombinant streptokinase. A differential scanning calorimetry study. J Protein Chem 200I, 20:9-17.

31. Sambrook J, Fritsch EF, Maniatis T: Molecular Cloning: a Laboratory Manual 2nd edition. New York: Cold Spring Harbor, Cold Spring Harbor Laboratory Press; 1989.

32. Kieser T, Bibb MI, Buttner MJ, Chater KF, Hopwood DA: Practical Streptomyces Genetics John Innes Foundation, Norwich, UK; 2000.

33. Anné J, Van Mellaert L, Eyssen $\mathrm{H}$ : Optimum conditions for efficient transformation of Streptomyces venezuelae protoplasts. Appl Microbiol Biotechnol 1990, 32:43 I-435.

34. Dyson P, Schrempf H: Genetic instability and DNA amplification in Streptomyces lividans 66. J Bacteriol 1987, 169:4796-4803.

35. Laemmli UK: Cleavage of structural proteins during the assembly of the head of bacteriophage T4. Nature 1970, 227:680-685.

36. Pimienta E, Fando R, Sanchez JC, Vallin C: Secretion of human interferon alpha $2 \mathrm{~b}$ by Streptomyces lividans. Appl Microbiol Biotechnol 2002, 58:189-194.
37. Bradford MM: A rapid and sensitive method for the quantitation of microgram quantities of proteins utilizing the principle of protein-dye binding. Anal Biochem 1976, 72:248-254.

38. Hernández L, Rodríguez P, Castro A, Serrano R, Rodríguez MP, Rubiera $R$, et al.: Determination of streptokinase activity by quantitative assay. Biotechnol Apl 1990, 7:153-160.

39. Ausubel FM, Brent R, Kingston RE, Moore DD, Smith JA, Seidman JG, et al:: Current Protocols in Molecular Biology John Wiley and Sons, New York; 1994.

40. Wehmeier UF: New multifunctional Escherichia coli-Streptomyces shuttle vectors allowing blue-white screening on XGal plates. Gene 1995, 165:149-150.
Publish with Bio Med Central and every scientist can read your work free of charge

"BioMed Central will be the most significant development for disseminating the results of biomedical research in our lifetime. "

Sir Paul Nurse, Cancer Research UK

Your research papers will be:

- available free of charge to the entire biomedical community

- peer reviewed and published immediately upon acceptance

- cited in PubMed and archived on PubMed Central

- yours - you keep the copyright
BioMedcentral 